\title{
Effects of a psychoeducational program for chronic pain management
}

\author{
Marina de Góes Salvetti ${ }^{1}$ \\ Andrea Cobelo ${ }^{2}$ \\ Patricia de Moura Vernalha ${ }^{3}$ \\ Carmen Ilca de Almeida Vianna ${ }^{4}$ \\ Luciana Cristina Carvalho Costa Campos Canarezi ${ }^{5}$ \\ Renata Gomes Lacerda Calegare ${ }^{6}$
}

Aims: to evaluate the impact of an eight-week psychoeducational program focused on pain intensity, disability and depressive symptoms of patients with chronic pain. Method: 79 patients with chronic pain of different etiologies composed the sample. Patients were assessed before, at the end of the intervention and six months after the intervention. The program was developed by a nurse using cognitive-behavioral strategies and was conducted by a multidisciplinary team. The Wilcoxon test was used to compare repeated measures. Results: the participants' mean age was 53 years old, most were female (91\%), with an average of 9.5 years of schooling and an average pain duration of 9.9 years. Significant reduction in pain intensity $(p<0.001)$, disability $(p<0.001)$ and depressive symptoms $(p<0.001)$ was found at the end of the program. Conclusions: the psychoeducational program was effective in reducing pain intensity, reducing disability and in controlling depressive symptoms in this sample.

Descriptors: Pain; Disabled Persons; Depression; Cognitive Therapy; Behavioral Therapy.

\footnotetext{
${ }^{1} \mathrm{PhD}$, Professor, Departamento de Enfermagem, Faculdade de Ciências Medicas, Universidade Estadual de Campinas (Unicamp), Brazil.

2 Psychologist, Specialist in Psychology in Psychiatry, Unimed, São Roque, SP, Brazil.

3 Psychologist, Specialist in Psychiatry and Addiction, Unimed, São Roque, SP, Brazil.

${ }^{4}$ Physical Therapist, Specialist in Global Postural Re-education, Dermatology and Acupuncture, Unimed, São Roque, SP, Brazil.

${ }^{5}$ Occupational Therapist, Specialist in Pediatric Neurology and Hand Therapy, Unimed, São Roque, SP, Brazil.

${ }^{6}$ Nutritionist, Specialist in Exercise Physiology, Orthomolecular Medicine and Teaching in Higher Education, Unimed, São Roque, SP, Brazil.
}

Corresponding Author: 


\section{Efeitos de um programa psicoeducativo no controle da dor crônica}

Objetivos: avaliar o impacto de um programa psicoeducativo de oito semanas na intensidade da dor, incapacidade e sintomas depressivos de pacientes com dor crônica. Método: setenta e nove pacientes com dor crônica de diferentes etiologias compuseram a amostra. Os participantes foram avaliados antes e ao final do programa e seis meses após. O programa foi desenvolvido por uma enfermeira, utilizaram-se estratégias cognitivocomportamentais, aplicadas por equipe multidisciplinar. O teste não paramétrico de Wilcoxon foi utilizado para comparar medidas repetidas. Resultados: a maioria dos participantes era do sexo feminino (91\%), com idade média de 53 anos, escolaridade média de 9,5 anos e duração média da dor de 9,9 anos. Ao final do programa, observouse redução significativa na intensidade da dor $(p<0,001)$, incapacidade $(p<0,001)$ e sintomas depressivos $(p<0,001)$. Conclusões: o programa psicoeducativo foi efetivo no controle da dor, na redução da incapacidade e no controle dos sintomas depressivos na amostra estudada.

Descritores: Dor; Pessoas com Deficiência; Depressão; Terapia Comportamental; Terapia Cognitiva.

\section{Efectos de un programa psicoeducativo en el control del dolor crónico}

Objetivos: evaluar el impacto de un Programa psicoeducativo de ocho semanas en la intensidad del dolor, incapacidad y síntomas depresivos de pacientes con dolor crónico. Método: 79 pacientes con dolor crónico de diferentes etiologías compusieron la muestra. Los participantes fueron evaluados antes y al final del Programa y seis meses después. El Programa fue desarrollado por una enfermera, utilizó estrategias cognoscitivo-comportamentales y fue aplicado por un equipo multidisciplinar. La prueba no paramétrico de Wilcoxon fue utilizado para comparar medidas repetidas. Resultados: la mayoría de los participantes eran del sexo femenino $(91 \%)$, con edad media de 53 años, escolaridad media de 9,5 años y duración media del dolor de 9,9 años. Al final del Programa se observó reducción significativa en la intensidad del dolor $(p<0.001)$, incapacidad $(p<0.001)$ y síntomas depresivos $(p<0.001)$. Conclusiones: el Programa psicoeducativo fue efectivo en el control del dolor, en la reducción de la incapacidad y en el control de los síntomas depresivos en la muestra estudiada.

Descriptores: Dolor; Personas con Discapacidad; Depresión; Terapia Cognitiva; Terapia Conductista.

\section{Introduction}

Chronic pain is a frequent problem in the most diverse populations. Brazilian studies show a prevalence of chronic pain of between $20 \%$ and $50 \%{ }^{(1-2)}$. Studies conducted in developed countries report a prevalence of chronic pain between $19 \%$ and $40 \%{ }^{(3-4)}$.

Pain is considered chronic when it is continuous or recurrent and lasts more than three months. Chronic pain has a negative impact on an individual's quality of life, affecting sleep, diet, relationships, ability to work, and functionality, among other aspects of daily life.
Chronic pain management programs have been developed to enable relief for pain, to improve patient functionality, reduce depressive symptoms, and improve the quality of life of individuals with chronic pain. Programs can use different approaches and generally are implemented in groups by interdisciplinary teams with a cognitive-behavioral emphasis ${ }^{(5-6)}$.

Cognitive-Behavioral Therapy (CBT) has been effective and widely used by different programs to manage pain and is considered to be the basis of many pain management 
programs $^{(7)}$. Psychoeducational interventions with a cognitive-behavioral emphasis include pain education, encouragement of self-confidence, establishment of goals, establishment of rhythm for activities, training in coping strategies, relaxation techniques, cognitive restructuring, problem-solving techniques, modification of painful behaviors and exercises ${ }^{(8-10)}$.

CBT for managing pain is based on the principle that the experience of pain results in a complex interaction among biological, cognitive, affective and behavioral factors and that changing these factors should positively affect the painful experience ${ }^{(11)}$.

Chronic pain management intervention based on these principles was developed in a preventive medicine private service taking into account evidence available concerning the benefits of multidisciplinary programs with a psychoeducational focus to manage chronic pain. This study's objective was to evaluate the impact of this program on a group of patients with chronic pain.

\section{Method}

This quasi-experimental study addresses a population composed of individuals with chronic pain of different etiologies. Inclusion criteria were: continuous or recurrent pain for at least three months and preserved communication and comprehension abilities. The patients were included in the program based on medical referral. The study was conducted in the Preventive Medicine Unit of a private health service.

A total of 133 patients enrolled in the Chronic Pain Management Program were included from May 2010 to May 2011, divided into six different groups. Among the patients who registered for the program: $48(36 \%)$ presented low treatment adherence (either abandoned the program or attendance was below $60 \%$ ) and were not included in the results' analysis. Among the 85 participants who completed the program with good treatment adherence, six provided incomplete information and were also excluded from the analysis.

Therefore, this study's sample was composed of a non-probabilistic sample of 79 patients who were assessed before and after the program. Even though all the patients were invited for a follow-up assessment (six months after the intervention), only 29 participants attended the third assessment (Figure 1).

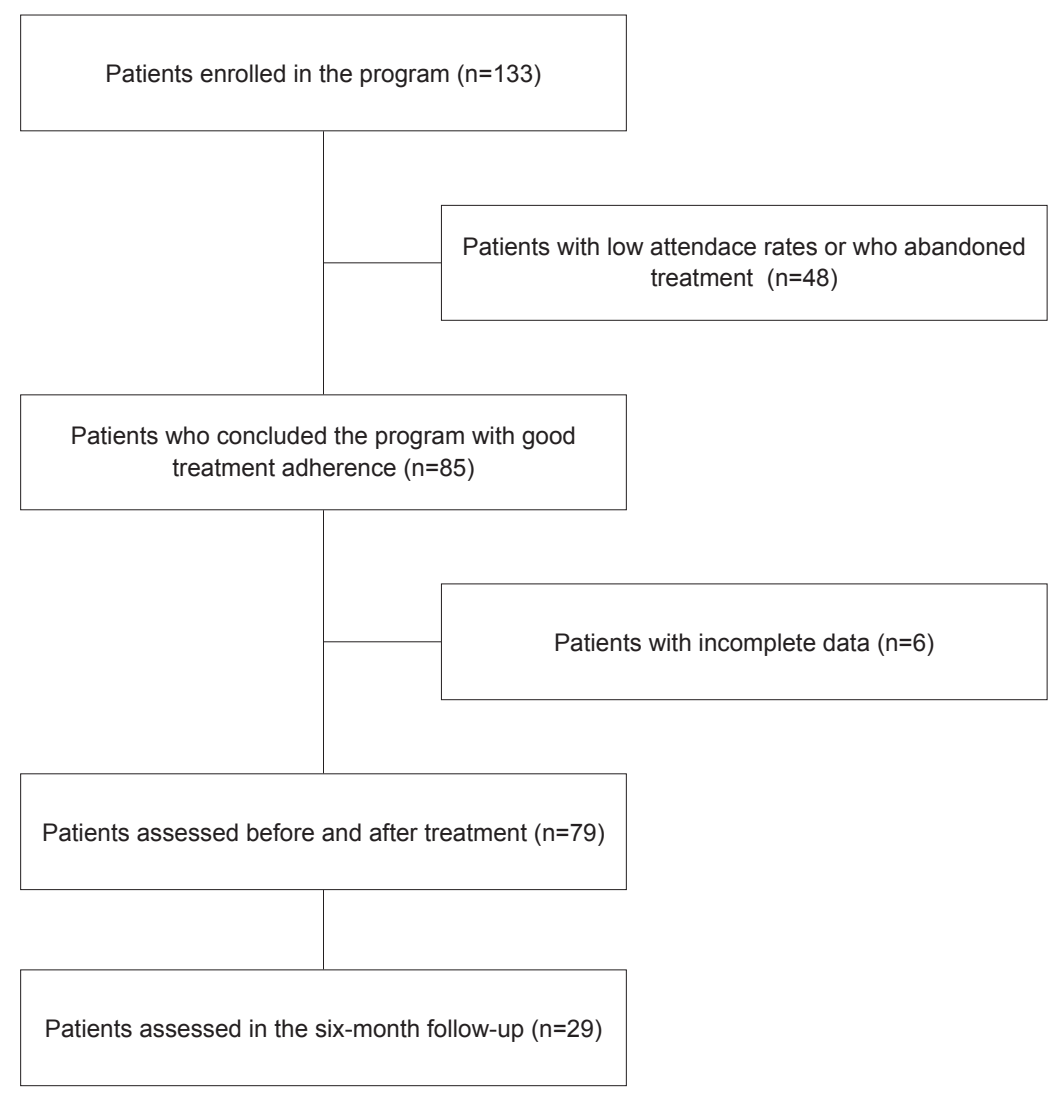

Figure 1 - Flowchart of patients during the study period 


\section{Intervention}

The intervention, called Chronic Pain Management Program, was headed by a nurse and based on psychoeducational programs implemented in developed countries $^{(12-13)}$

The Chronic Pain Management Program had a psychoeducational approach with a cognitive-behavioral focus. This intervention's objectives were to reduce pain intensity, pain-related disability and depressive symptoms in patients with chronic pain.

The intervention was implemented by an interdisciplinary team to facilitate the self-management of pain and improve the individuals' physical and psychological functionality. The program was organized into 16 meetings distributed over eight weeks, two weekly sessions of two hours duration, totaling 32 hours. In each session, the patients performed one hour of stretching with a physical therapist and one hour of psychoeducational group with a nurse and a psychologist. The program also included two sessions with an occupational therapist and one session with a nutritionist.

The themes addressed in the programs were: differences between acute and chronic pain, the basic physiology of pain, chronic pain management, the importance of exercise and stretching to controlling pain, emotional responses to pain, identifying and changing dysfunctional beliefs, problem-solving techniques, relaxation techniques, using rhythm to manage pain, a healthy diet, posture and functionality. The participants learned strategies to facilitate pain management and also worked with emotions and thoughts that affect and/ or are affected by pain. Figure 2 presents an overview of the program's content.

\begin{tabular}{|c|c|c|c|c|c|c|c|c|}
\hline \multicolumn{9}{|c|}{ Chronic pain management program } \\
\hline & \multicolumn{8}{|c|}{ Week } \\
\hline & 1 & 2 & 3 & 4 & 5 & 6 & 7 & 8 \\
\hline Presentation of the program and overview of pain management & $\mathrm{x}$ & & & & & & & \\
\hline Stretching and muscle strengthening & $\mathrm{x}$ & $\mathrm{x}$ & $\mathrm{x}$ & $\mathrm{x}$ & $\mathrm{x}$ & $\mathrm{x}$ & $\mathrm{x}$ & $\mathrm{x}$ \\
\hline Relaxation techniques & $\mathrm{x}$ & $\mathrm{x}$ & $\mathrm{x}$ & $\mathrm{x}$ & $\mathrm{x}$ & $\mathrm{x}$ & $\mathrm{x}$ & $\mathrm{x}$ \\
\hline Identifying thoughts and emotions (CBT*) & & $\mathrm{x}$ & $\mathrm{x}$ & $\mathrm{x}$ & $\mathrm{x}$ & $\mathrm{x}$ & $\mathrm{x}$ & $\mathrm{x}$ \\
\hline Basic physiology of pain & $\mathrm{x}$ & & & & & & & \\
\hline Importance of exercise to managing pain & & $\mathrm{x}$ & & & & & & \\
\hline Assessment and guidance concerning daily life activities & & & $\mathrm{x}$ & & $\mathrm{x}$ & & & \\
\hline Medication for pain relief & & & $\mathrm{x}$ & & & & & \\
\hline Physical therapy to manage pain & & & & $\mathrm{x}$ & & & & \\
\hline Using rhythm to manage pain & & & & $\mathrm{x}$ & & & & \\
\hline Psychotherapy to manage pain & & & & & $\mathrm{x}$ & & & \\
\hline Problem-solving techniques & & & & & & $\mathrm{x}$ & & \\
\hline Healthy diet & & & & & & $x$ & & \\
\hline Improving sleep & & & & & & & $\mathrm{x}$ & \\
\hline Making plans (maintaining obtained results) & & & & & & & & $\mathrm{x}$ \\
\hline
\end{tabular}

*CBT (Cognitive Behavioral Therapy)

Figure 2 - Overview of the chronic pain management program

\section{Measurement instruments}

The program's participants were assessed at three points in time: before initiating the program, at the end of the program (after eight weeks) and six months after the intervention. The patients' assessment included a form with demographic data and three scales validated for the Portuguese language to evaluate intensity of pain, pain-related disability, and depressive symptoms, which are described as follow.

The intensity of pain was assessed by the Numerical Pain Scale (NPS) and includes the following statement:
Please, tell me the average intensity of your pain in the last week, considering 0 as no pain and 10 as the worst pain you can imagine. NPS is easily applied and has been widely used in pain research. The NPS' process of validation was well documented and studies show significant positive correlations with other measures of pain intensity ${ }^{(14)}$.

Disability was measured by the Oswestry Disability Index (ODI), version 2.0, which focuses on the impact of pain on daily living activities and is related to the definition of disability provided by the World Health Organization $^{(15)}$. The scale consists of 10 items or 
sections ranging from 0 to 5 . The first item assesses the intensity of pain and the remaining items assess the effects of pain on daily activities. The total score ranges from 0 to 100 (no disability to total disability) (15). The score is computed by totaling the points obtained in all the sections and dividing this total by the maximum number of points one can score in all the sections $^{(15)}$. The validation of the scale in Portuguese presented very good internal consistency (Cronbach's alpha $=0.87$ ) and excellent reliability in the test-retest $(0.99)^{(16)}$.

Depression was assessed through the Beck Depression Inventory (BDI), developed to evaluate depressive symptoms ${ }^{(17)}$ and validated for the Portuguese language by Gorenstein, Andrade $(1998)^{(18)}$. The BDI is composed of 21 items with statements ranging from 0 to 3 and reflects the intensity of one's symptoms. The instrument's minimum score is 0 and the maximum score is 63. The cutoff points for populations without previous diagnosis of depression are: scores between 16 and 20 indicate dysphoria and 21 or higher indicate depression(17). The psychometric properties of the BDI in the Portuguese language were tested and the instrument's internal consistency was checked through Cronbach's alpha $(0.81)^{(18)}$.

\section{Ethical aspects}

The participants were informed of the study's objectives and signed two copies of free and informed consent forms before initiating the treatment. The study project was approved by the Coordination of Preventive Medicine of Unimed São Roque and by the Ethics Research Committee at the Unimed São Roque Hospital (Process 01/2012).

\section{Data analysis}

Data were stored and analyzed in the database of the statistical program STATA, version 11.0 (StataCorp LP, College Station, Texas, USA). First, descriptive analysis of the study's variables was performed. The results for the qualitative variables are presented in frequency tables. Estimates of central tendency and dispersion measures were performed for the quantitative variables.

In order to compare the quantitative variables after non-normality was verified through the Kolmogorov-Smirnov non-parametric test, Wilcoxon's non-parametric test was used to compare repetitive measures.

\section{Results}

\section{Participants}

The participants' characteristics are described in Table 1 . The average duration of pain reported by the participants was 9.9 years.

Table 1 - Characterization of the sample in the pain management program

\begin{tabular}{lc}
\hline \multicolumn{1}{c}{ Variables } & (n=79) \\
\hline Female gender & $72(91.1 \%)$ \\
Employment status & \\
Active & $23(29.1 \%)$ \\
On sick leave & $15(19.0 \%)$ \\
Retired & $27(34.2 \%)$ \\
Homemaker & $13(16.5 \%)$ \\
Unemployed & $1(1.3 \%)$ \\
Etiology of pain & \\
Fibromyalgia & $42(53.2 \%)$ \\
Back pain & $13(16.4 \%)$ \\
Tendinitis & $4(5.1 \%)$ \\
Arthritis & $4(5.1 \%)$ \\
Herniated disc & $4(5.1 \%)$ \\
Others & $12(15.1 \%)$ \\
\hline \multicolumn{1}{c}{ Variables } & average (SD) \\
\hline Age (in years) & $53.2(11.0)$ \\
Education (in years) & $9.5(4.8)$ \\
\hline
\end{tabular}

$\mathrm{SD}=$ standard deviation

\section{Effects of the intervention}

The assessment of patients who completed the program revealed a significant reduction in scores of pain intensity, disability, and depressive symptoms, as shown in Table 2.

Table 2 - Descriptive statistics of the scores concerning pain intensity, disability and depression before and after the program

\begin{tabular}{|c|c|c|c|c|c|}
\hline \multirow{2}{*}{ Variable } & \multicolumn{2}{|c|}{ Before the program $(n=79)$} & \multicolumn{2}{|c|}{ After the program $(n=79)$} & \multirow{2}{*}{$P$ value } \\
\hline & Average (SD) & Median (min-max) & Average (SD) & Median (min-max) & \\
\hline Intensity of pain (1 to 10 ) & $7.5(1.8)$ & $8(1-10)$ & $4.9(2.6)$ & $5(0-10)$ & $<0.001$ \\
\hline Disability ( $2 \%$ to $70 \%)$ & $32.8(15.1)$ & $34(2-70)$ & $24.0(13.4)$ & $22(0-66)$ & $<0.001$ \\
\hline Depression (0 to 42 ) & $14.6(9.6)$ & $13(0-42)$ & $8.9(8.3)$ & $7(0-44)$ & $<0.001$ \\
\hline
\end{tabular}

$\mathrm{SD}=$ standard deviation 
The results concerning the follow-up $(n=29)$ show that patients maintained the results obtained for pain intensity (average $=42$ ) and depressive symptoms (average $=7.8$ ) and presented reduced scores for disability (average $=12.5$ ) compared to the assessment at the end of the program.

\section{Discussion}

The study shows that the Chronic Pain Management Program significantly reduced the intensity of pain, disability and depressive symptoms of patients with chronic pain in the studied sample.

The results found in this study confirm those reported in the literature, which is evidence for the benefits of this type of treatment for chronic pain management. A meta analysis investigating the efficiency of psychological interventions designed to manage chronic back pain confirmed the efficiency of these interventions in reducing pain, the degree of disability and depressive symptoms in individuals with chronic back pain ${ }^{(19)}$.

A study reporting the results of an analysis of random studies using $\mathrm{CBT}$ in the treatment of chronic pain concluded that treatments based on this approach produced significant improvements in the patients' pain, mood, coping strategies, painful behavior, level of activity, and social performance ${ }^{(20)}$.

A Brazilian study analyzing the effects of CBT on the nociceptive responsiveness of women with fibromyalgia found that CBT increased the pain threshold in this group of patients ${ }^{(21)}$.

There is also a literature review reporting evidence that intensive rehabilitation with a cognitive-behavioral emphasis is equivalent to the results of spine fusion surgery in improving pain and functionality for patients with back pain(6).

The comparison of averages obtained in this study before and after the program showed statistical significance but it is worth considering whether this difference is clinically relevant. There are reports that any decrease in pain intensity scores that can be considered to be clinically relevant ranges from 2.5 to 4.5 on scales from 0 to $10^{(22-23)}$. A decrease of 2.6 points was observed in this study when comparing pain intensity scores before and after the intervention. Therefore, the Chronic Pain Management Program significantly reduced pain intensity from both the statistical and clinical point of views.

In regard to the clinically relevant difference for the disability score, only one study was found using the same scale (ODI) and those authors report that a difference of 12 points is clinically significant ${ }^{(24)}$. The difference found in this study in the average disability score before and after the intervention was 8.8 points, which would not be considered a clinically relevant difference. The difference, however, among the patients who attended follow-up was 20.3 points, which shows clinical relevance. It is worth keeping in mind that most patients who participated in the follow-up assessment kept exercising after the intervention ended, which may have led to a progressive reduction of disability in this group of patients.

Even though a statistically significant difference was found concerning changes in the depression scores among patients with chronic pain, no studies reporting significant clinical differences were found.

This study has some limitations that should be noted. First, there is a limited possibility of generalizing results considering we used a convenience sample and, even though it includes patients with different etiologies, the sample was composed of patients using a private service. Therefore, this sample does not necessarily characterize the population with chronic pain in general. Secondly, the lack of a control group may also be considered a limitation since comparison between two groups exposed to the same intervention is not possible. These limitations should be addressed in future studies.

Even though there are some restrictions concerning the interpretation of results, this study has some strengths. One of these is the description of an efficient intervention to manage chronic pain that can be used in different contexts to alleviate the suffering of patients with persistent pain. Another strong point is that its results confirm the benefits of interdisciplinary interventions with a cognitive-behavioral approach in managing chronic pain through short-duration interventions.

\section{Conclusions}

The results show that the Chronic Pain Management Program was efficient in reducing scores concerning pain intensity, pain-related disability and depressive symptoms in the studied sample. These effects persisted over a period of six months. This intervention can be used in specialized pain management centers, rehabilitation centers or preventive medicine services.

\section{References}

1. Sá KN, Baptista AF, Matos MA, Lessa I. Chronic pain and gender in Salvador population, Brazil. Pain. 2008;139:498-506. 
2. Kreling MCGD, Cruz DALM, Pimenta CAM. Prevalência da dor crônica em adultos. Rev Bras Enfermagem. 2006;59:509-13.

3. Picavet HSJ, Schouten JSAG. Mukuloskeletal pain in the Netherlands: prevalences, consequences and risk groups, the DMC3-study. Pain. 2003;102:167-78.

4. Eriksen J, Jensen $M K$, Sjogren $P$, Ekholm O, Rasmussem NK. Epidemiology of chronic non-malignant pain in Denmark. Pain. 2003;106:221-8.

5. Bechelli LPC, Santos MA. Psicoterapia de grupo: como surgiu e evoluiu. Rev. Latino-Am. Enfermagem. 2004;12(2):242-9.

6. Chou R, Loeser JD, Owens DK, Rosenquist RW, Atlas SJ, Baisden J, et al. Interventional therapies, surgery, and interdisciplinary rehabilitation for low back pain. Spine. 2009;34(10):1066-77.

7. Wells-Federman C, Arnstein P, Caudill M. Nurse-Led Pain Management Program: Effect on self-efficacy, pain intensity, pain-related disability, and depressive symptoms in chronic pain patients. Pain Manage Nurs. 2002;3(4):131-40.

8. Richardson C, Adams N, Poole H. Psychological approaches for the nursing management of chronic pain: part 2. J Clin Nurs. 2006;15:1196-202.

9. Brox JI, Storheim K, Grotle M, Tveito TH, Indahl A, Eriksen HR. Systematic review of back schools, brief education and fear-avoidance training for chronic low back pain. Spine J. 2008;8:948-58.

10. Ortega E, Garcia JJ, Bote ME, Martin-Cordero L, Escalante $Y$, Saavedra JM et al. Exercise in fibromyalgia and related inflammatory disorders: know effects and unknown chances. Exerc Immunol Rev. 2009;15:42-65. 11. Thieme K, Gracely RH. Are psychological treatments effective for fibromyalgia pain? Curr Rheumatol Rep. 2009; 11:443-50.

12. McGillion MH, Watt-Watson J, Stevens B, LeFort SM, Coyte P, Graham A. Randomized Controlled Trial of a Psychoeducation Program for the Self-Management of Chronic Cardiac Pain. J Pain Symptom Manage. 2008;36(2):126-38.

13. Marks R, Allegrante JP, Lorig K. A review and synthesis of research evidence for self-efficacyenhancing interventions for reducing chronic disability: implications for health education practice (Part I). Health Promotion Pract. 2005;6(1):37-43.
14. Jensen MP, Karoly P. Self-Report Scales and procedures for Assessing Pain in Adults. In: Turk, Melzack. Handbook of Pain Assessment. New York: Guilford Press; 2001. p. 19-44.

15. Fairbank JCT, Pynsent PB. The Oswestry Disability Index. Spine. 2000;25(22):2940-53.

16. Vigatto $R$, Alexandre NMC, Correa-Filho HR. Development of a Brasilian Portuguese Version of the Oswestry Disability Index: Cross-Cultural Adaptation, Reliability and Validity. Spine. 2007;32(4):481-6.

17. Beck AT, Steer RA, Garbin MG. Psychometric properties of the Beck depression inventory: twenty-five years of evaluation. Clin Psychol Rev. 1988;8:77-100.

18. Gorestein C, Andrade L. Inventário de Depressão de Beck: propriedades psicométricas da versão em português. Rev Psiquiatria Clín. - Edição Especial 1998;25(5):245-50.

19. Hoffman BM, Papas RK, Chatkoff DK, Kerns RD. Meta-analysis of psychological interventions for chronic low back pain. Health Psychol. 2007;26(1):1-9.

20. Morley S, Eccleston C, Williams A. Systematic review and meta-analysis of randomized controlled trials of cognitive behavior therapy and behavior therapy for chronic pain in adults, excluding headache. Pain. 1999;80:1-13.

21. Chakr RMS. Efeitos da terapia cognitivocomportamental na responsividade nociceptiva de mulheres com fibromialgia [dissertação de mestrado]. Porto Alegre (RS): Faculdade de Medicina da Universidade Federal do Rio Grande do Sul; 2011. 79 p.

22. Kovacs FM, Abraira V, Royuela A, Corcoll J, Alegre $L$, Cano A, et al. Minimal clinically important change for pain intensity and disability in patients with nonspecific low back pain. Spine. 2007;32(25):2915-20.

23. van der Roer N, Ostelo RWJG, Bekkering GE, van Tulder MW, de Vet HCW. Minimal clinically important change for pain intensity, functional status, and general health status in patients with nonspecific low back pain. Spine. 2006;31(5):578-82.

24. Lauridsen $\mathrm{HH}$, Hartvigsen J, Manniche C, Korsholm L, Grunnet-Nilsson N. Responsiveness and minimal clinically important difference for pain and disability instruments in low back pain patients. BMC Muskuloskeletal Disorders. 2006;7:82. 